\title{
Effective Reduction of Chromium-oxy-hydroxide Evaporation from Ni-Base Alloy 690
}

\author{
T. Sand ${ }^{1}$ (D) $\cdot$ C. Geers ${ }^{1} \cdot$ Y. Cao ${ }^{2} \cdot$ J. E. Svensson ${ }^{1} \cdot$ L. G. Johansson ${ }^{1}$
}

Received: 25 March 2019 / Revised: 16 August 2019 / Published online: 29 August 2019

(c) The Author(s) 2019

\begin{abstract}
The corrosion of the Ni-base alloy $690(60 \mathrm{Ni}, 30 \mathrm{Cr}$ and $10 \mathrm{Fe})$ in humidified air was studied at $500-800{ }^{\circ} \mathrm{C}$, and the rate of $\mathrm{CrO}_{2}(\mathrm{OH})_{2}$ volatilization was measured quantitatively as a function of exposure time using a denuder technique. Different gas velocities were employed in exposures with a maximum duration of $200 \mathrm{~h}$. Corrosion morphology was investigated by SEM/EDX using BIB-milled cross sections. The rate of chromium volatilization increased with increasing temperature and gas velocity. The rate of volatilization decreased with exposure time. Two oxide scale morphologies were observed, depending on temperature and gas velocity. In the 500-700 ${ }^{\circ} \mathrm{C}$ range, the scale consisted of chromia-rich corundum-type oxide, while exposures with high gas velocities at $800{ }^{\circ} \mathrm{C}$ produced an entirely different type of scale that included a Ni-rich and Cr-poor cap layer. The latter scale morphology is suggested to result from extensive chromium depletion of the alloy substrate which triggers a new mode of oxidation involving formation of $\mathrm{NiCr}$ spinel oxide. Continued volatilization of $\mathrm{CrO}_{2}(\mathrm{OH})_{2}$ causes the $\mathrm{NiCr}$ spinel to decompose into a Ni-rich oxide that forms a cap layer on the scale surface. This cap layer is very efficient in decreasing the rate of chromium volatilization, allowing the chromium levels in the substrate to recuperate. We show that volatilization of chromium (VI) from the alloy can be mitigated by an oxidation pre-treatment that allows the Ni-rich cap layer to form.
\end{abstract}

Keywords Ni-base alloys · Oxidation · Pre-treatment $\cdot$ Cr evaporation · Gas flow velocity $\cdot$ Water vapour

T. Sand

tommy.sand@chalmers.se

1 Department of Chemistry and Chemical Engineering, Chalmers University of Technology, 41296 Gothenburg, Sweden

2 Department of Industrial and Materials Science, Chalmers University of Technology, 41258 Gothenburg, Sweden 


\section{Introduction}

It is well known that exposure of metals and alloys to high-temperature environments containing a combination of $\mathrm{O}_{2}$ and $\mathrm{H}_{2} \mathrm{O}$ can result in evaporation of oxyhydroxide compounds [1]. In a corrosion context, the most important such species is chromium-oxy-hydroxide, $\mathrm{CrO}_{2}(\mathrm{OH})_{2}$ :

$$
\frac{1}{2} \mathrm{Cr}_{2} \mathrm{O}_{3}(s)+\frac{3}{4} \mathrm{O}_{2}(g)+\mathrm{H}_{2} \mathrm{O}(g) \rightleftarrows \mathrm{CrO}_{2}(\mathrm{OH})_{2}(g)
$$

In humid air, $\mathrm{CrO}_{2}(\mathrm{OH})_{2}$ is the dominant volatile chromium species up to very high temperatures $[2,3]$. Thus, in a gas with $\mathrm{P}\left(\mathrm{O}_{2}\right)=\mathrm{P}\left(\mathrm{H}_{2} \mathrm{O}\right)=0.1$ atm at $800{ }^{\circ} \mathrm{C}$, the equilibrium vapour pressures of other chromium-containing species such as $\mathrm{CrO}_{3}$ and $\mathrm{CrO}_{2}(\mathrm{OH})$ are reported to be $<1 \%$ compared to $\mathrm{CrO}_{2}(\mathrm{OH})_{2}[2,3]$. Volatilization of $\mathrm{CrO}_{2}(\mathrm{OH})_{2}$ can cause problems for alloys that rely on forming a protective chromia scale, i.e. for stainless steels and Ni-base alloys. Thus, chromium volatilization depletes the oxide scale and the near-surface region of the alloy in chromium. In the case of stainless steels, this may cause the protective chromia scale to be replaced by less protective and faster growing oxides such as spinel and iron oxides, resulting in so-called breakaway oxidation [1, 4]. Ni-base alloys with low amounts of iron are not likely to form iron oxide scales [5]. Instead, in studies of the rather chromium lean alloy 600, oxidation of nickel has been observed. Thus, an outer layer consisting of $\mathrm{NiO}$ and $\mathrm{NiCr}_{2} \mathrm{O}_{4}$ was reported to form in humid air $\left(0-19 \% \mathrm{H}_{2} \mathrm{O}\right)$ environments in the range $600-900{ }^{\circ} \mathrm{C}$ [6]. In addition, volatilization of $\mathrm{CrO}_{2}(\mathrm{OH})_{2}$ can have other detrimental effects depending on the application, e.g. cathode poisoning in solid oxide fuel cells (SOFCs) [7].

According to Reaction (1), the equilibrium vapour pressure of $\mathrm{CrO}_{2}(\mathrm{OH})_{2}$ over solid chromia is proportional to the product $\mathrm{P}\left(\mathrm{H}_{2} \mathrm{O}\right) \times \mathrm{P}\left(\mathrm{O}_{2}\right)^{0.75}$. In an equilibrium situation (very low flow rates and large surface area of $\mathrm{Cr}_{2} \mathrm{O}_{3}$ ), the rate of vaporization is directly proportional to flow rate. In contrast, at very high flow rates, chromium volatilization will eventually become independent of flow rate, being limited only by the rate of the forward reaction in Reaction (1). Working with $\mathrm{FeCr}$ alloys in air with $3 \% \mathrm{H}_{2} \mathrm{O}$, Froitzheim et al. reported that the rate of chromium volatilization was independent of flow rate above a net gas velocity of about $25 \mathrm{~cm} / \mathrm{s}$ [8]. However, a recent investigation showed that for an air/6\% $\mathrm{H}_{2} \mathrm{O}$ gas mixture at $900{ }^{\circ} \mathrm{C}$ the rate of chromium volatilization increased significantly when the flow velocity was increased from 70 to $6000 \mathrm{~cm} / \mathrm{s}$ [9]. The present study is carried out under conditions that are intermediate between the equilibrium regime and the reactioncontrolled regime, meaning that while the rate of volatilization is not proportional to flow rate, it does increase with flow rate. According to [2], $K_{p}$ for Reaction (1) is $10^{-5.1}$ at $800{ }^{\circ} \mathrm{C}$ and $10^{-5.6}$ at $600{ }^{\circ} \mathrm{C}$, showing that, at constant gas composition, the equilibrium vapour pressure of $\mathrm{CrO}_{2}(\mathrm{OH})_{2}$ over $\mathrm{Cr}_{2} \mathrm{O}_{3}(\mathrm{~s})$ increases slowly with temperature. In the reaction-limited regime, the temperature dependence of the rate of volatilization is given by the activation energy for the forward Reaction (1), which has been calculated to be $83 \mathrm{~kJ} / \mathrm{mol}$ [10] and experimentally evaluated to 91-92 kJ/mol [11]. A previous investigation using experimental techniques similar 
to this work measured the rate of chromium volatilization from two ferritic steels in air with $3 \% \mathrm{H}_{2} \mathrm{O}$. They reported that in the temperature range $650{ }^{\circ} \mathrm{C}$ to $850{ }^{\circ} \mathrm{C}$, a $100{ }^{\circ} \mathrm{C}$ increase in temperature caused the evaporation rate to increase by a factor of 2-3 [11].

Volatilization of $\mathrm{CrO}_{2}(\mathrm{OH})_{2}$ from chromia involves oxidation of chromium (III) at the $\mathrm{Cr}_{2} \mathrm{O}_{3}$ surface to the hexavalent state by $\mathrm{O}_{2}$ and subsequent hydrolysis of the $\mathrm{Cr}(\mathrm{III})-\mathrm{O}-\mathrm{Cr}(\mathrm{VI})$ bonds by $\mathrm{H}_{2} \mathrm{O}$ [10]. Volatilization of $\mathrm{CrO}_{2}(\mathrm{OH})_{2}$ from a chromium-containing spinel oxide or from $\mathrm{Cr}_{2-\mathrm{x}} \mathrm{Fe}_{\mathrm{x}} \mathrm{O}_{3}$ essentially occurs in the same way, except that the energetics of volatilization are less favourable, meaning that the equilibrium vapour pressure is lower. Also, $\mathrm{CrO}_{2}(\mathrm{OH})_{2}$ volatilization from a mixed oxide depletes the oxide surface in chromium, implying that the rate of chromium volatilization may become limited by solid-state diffusion of $\mathrm{Cr}^{3+}$ to the scale surface. Thus, the rate of chromium volatilization from a chromia-forming alloy can be decreased by designing it to form mixed chromium-containing oxides on the scale surface. This approach to mitigate chromium volatilization is widely used with ferritic $\mathrm{FeCr}$ steels for SOFC applications where alloying with manganese is used in order to form a duplex scale featuring a $\mathrm{MnCr}_{2} \mathrm{O}_{4}$ "cap" layer and a bottom $\mathrm{Cr}_{2} \mathrm{O}_{3}$ layer $[11,12]$. Indeed, the presence of a spinel oxide acting as a protective barrier against evaporation has shown to reduce the evaporation significantly [12-14].

Tedmon [15] investigated the general case of a metal which, when subjected to oxidation, forms a solid scale that grows parabolically in thickness with a rate constant $k_{d}$ and where the scale simultaneously loses thickness (e.g. due to volatilization) at a constant rate $k_{s}$ :

$$
\frac{\mathrm{d} X}{\mathrm{~d} t}=\frac{K_{d}}{X}-k_{s}
$$

According to Eq. 1, there is a limiting scale thickness $X=k_{d} / k_{s}$ (see [16] for a corresponding generalized expression of paralinear kinetics for gravimetric data). While Tedmon's working example was pure chromium exposed to $\mathrm{H}_{2} \mathrm{O}+\mathrm{O}_{2}$ environment at high temperature and is thus relatively close to the present work, Eq. 1 does not consider several factors that will influence scale growth and scale volatilization for alloys, i.e. diffusion of the oxide-forming element in the metal, diffusion in the scale and changes in scale composition.

Besides participating in the formation of volatile oxy-hydroxide species, water vapour has been reported to change the microstructure of the scale and affect the internal and external oxidation behaviour, the ion transport properties of the scale as well as the overall oxidation rate [17-20].

This work investigates the oxidation properties and chromium volatilization behaviour of the Ni-base alloy 690 in humid air. We focus on the consequences of chromium loss on oxidation and investigate the changes in corrosion behaviour and scale morphology triggered by extensive chromium depletion of the scale and the underlying substrate. 


\section{Experimental Procedures}

\section{Material}

Alloy 690 samples with nominal size $12 \times 12 \times 1 \mathrm{~mm}$ were cut from a solid bar with a diameter of $121 \mathrm{~mm}$; see Table 1 for the chemical composition. The bar was produced by electric arc furnace and argon oxygen decarburization (EAF+AOD) followed by continuous casting into a bloom which was hot-forged down to final dimension. A final heat treatment was performed in order to achieve a uniform grain structure. The average grain diameter was about $55 \mu \mathrm{m}$.

Before exposure, the flat coupon surfaces were ground and polished down to mirrorlike surface finish using 1- $\mu$ m diamond paste in the final step, while the edges were ground with $\mathrm{SiC}$ paper with \#1000 grit. After polishing and before exposure, the samples were cleaned in an ultrasonic bath at room temperature. The samples were first cleaned in acetone and then ethanol.

\section{Experimental Set-Up}

The exposures were performed in horizontal tube furnaces equipped with fused quartz tubes with the gas inlet on the one side and the outlet on the other side. Downstream of the samples, the gas flow passed through a so-called denuder tube; see [8] for a more detailed explanation of the set-up. The inside of the denuder tube was coated with $\mathrm{Na}_{2} \mathrm{CO}_{3}$ (s) which getters $\mathrm{CrO}_{2}(\mathrm{OH})_{2}(\mathrm{~g})$ as solid sodium chromate according to Reaction 2:

$$
\mathrm{CrO}_{2}(\mathrm{OH})_{2}(g)+\mathrm{Na}_{2} \mathrm{CO}_{3}(s) \rightarrow \mathrm{Na}_{2} \mathrm{CrO}_{4}(s)+\mathrm{H}_{2} \mathrm{O}(g)+\mathrm{CO}_{2}(g) .
$$

The denuder tube can be exchanged without interrupting the exposure, allowing for time-resolved measurement of chromium evaporation. The chromate is leached with water and quantified by photospectrometry using a Thermo Scientific Evolution ${ }^{\mathrm{TM}}$ 60S UV/Vis spectrophotometer at a wavelength of $370 \mathrm{~nm}$ and using a Merck Certipur ${ }^{\mathrm{TM}}$ chromate solution as a standard.

Compared to the set-up for collecting volatile chromium species described in [8], two modifications were made in this study. Firstly, the part of the denuder tube outside the furnace tube was provided with additional heating in order to avoid water condensation. The second modification was that the gas leaving the denuder tube was passed through a gas wash bottle containing water with a $\mathrm{pH}$ of about 12 . The wash bottle collects particles and unreacted chromium-oxy-hydroxide species entrained in the gas stream. Before analysis, the gas wash bottle solution was concentrated by evaporation on a hot plate.

Table 1 Chemical composition of the tested alloy in wt $\%$

\begin{tabular}{llllllll}
\hline Alloy & $\mathrm{Cr}$ & $\mathrm{Fe}$ & $\mathrm{Ni}$ & $\mathrm{C}$ & $\mathrm{Si}$ & $\mathrm{Mn}$ & $\mathrm{Ti}$ \\
\hline Alloy 690 & 29.6 & Bal. & 60.1 & 0.018 & 0.19 & 0.29 & 0.28 \\
\hline
\end{tabular}


Each exposure involved three identical samples that were placed in alumina sample holders with 1-mm slits. The samples were standing on their edge with the flat surface parallel to the gas stream. The exposure gas consisted of humidified ambient air, the air being purified using potassium permanganate filters. To achieve $20 \mathrm{vol} \%$ of water vapour in the exposure gas, the dew point was set to $60.4 \pm 0.3{ }^{\circ} \mathrm{C}$ using a condenser. A Michell Instruments Optidew Vision ${ }^{\mathrm{TM}}$ chilled mirror humidity sensor was used for calibration. The gas flow rate (measured as dry gas at $25^{\circ} \mathrm{C}, 1 \mathrm{~atm}$ ) was set to $1000 \pm 5 \mathrm{ml} / \mathrm{min}, 3000 \pm 5 \mathrm{ml} / \mathrm{min}, 6000 \pm 10 \mathrm{ml} / \mathrm{min}$ and $8000 \pm 10 \mathrm{ml} /$ min using a MesaLabs Defender TM 530+ flow meter for calibration. A flow restrictor, consisting of porous ceramic monolith, was positioned in the quartz tube upstream of the samples in order to achieve a homogenous gas flow. The temperatures at the sample position were set to $500{ }^{\circ} \mathrm{C} \pm 3{ }^{\circ} \mathrm{C}, 600{ }^{\circ} \mathrm{C} \pm 3{ }^{\circ} \mathrm{C}, 700{ }^{\circ} \mathrm{C} \pm 3{ }^{\circ} \mathrm{C}$ or $800{ }^{\circ} \mathrm{C} \pm 3{ }^{\circ} \mathrm{C}$. The exposure time was up to $200 \mathrm{~h}$, and the denuder tubes were replaced at intervals depending on exposure parameters.

Sample mass was recorded using a Sartorius ${ }^{\mathrm{TM}}$ 6-decimal balance.

\section{Analysis Methods}

After exposure, representative samples were cut in the cross-sectional direction and prepared for microstructure analysis. To avoid artefacts associated with manual cutting, grinding and polishing, a Leica TIC $3 \mathrm{X}^{\mathrm{TM}}$ was used to prepare the cross sections by broad ion beam (BIB) (Ga ion) milling. Top view and cross section samples were analysed by a FEI Quanta ${ }^{\mathrm{TM}} 200$ field emission gun scanning electron microscopy (FEG-SEM) equipped with energy-dispersive X-ray spectrometer (EDX).

Crystalline corrosion products were examined by X-ray diffraction (XRD) in a Siemens D5000 ${ }^{\mathrm{TM}}$ powder diffractometer using grazing incidence diffraction and a Göbel mirror. $\mathrm{Cu}-K_{\alpha}$ radiation was used with an incidence angle of $1^{\circ}$ and a process time of $10 \mathrm{~s}$.

Depth profiling of the oxide layer was performed by alternating argon ion-sputtering and X-ray photoelectron spectroscopy (XPS) measurements with an X-ray beam size of $100 \mu \mathrm{m}$. The XPS instrument was a VersaProbe ${ }^{\mathrm{TM}}$ III equipped with an $\mathrm{AlK}_{\alpha} \mathrm{X}$-ray source.

\section{Results}

\section{Influence of Temperature on Chromium Volatilization and Scale Morphology ( $20 \% \mathrm{H}_{2} \mathrm{O}$ and Low Gas Velocity)}

\section{Chromium-oxy-hydroxide Evaporation}

Figure 1 shows the net mass change in the samples and the corresponding chromium volatilization (expressed as $\mathrm{mg} / \mathrm{cm}^{2} \mathrm{Cr}_{2} \mathrm{O}_{3}$ ) after $90 \mathrm{~h}$ exposure in air with $20 \% \mathrm{H}_{2} \mathrm{O}$ at $500{ }^{\circ} \mathrm{C}, 600{ }^{\circ} \mathrm{C}, 700{ }^{\circ} \mathrm{C}$ and $800{ }^{\circ} \mathrm{C}$. The gas flow was $1000 \mathrm{ml} / \mathrm{min}$ (at $1 \mathrm{~atm}, 25^{\circ} \mathrm{C}$ ). At $500{ }^{\circ} \mathrm{C}$ and $600{ }^{\circ} \mathrm{C}$, mass gains were recorded, while the samples 


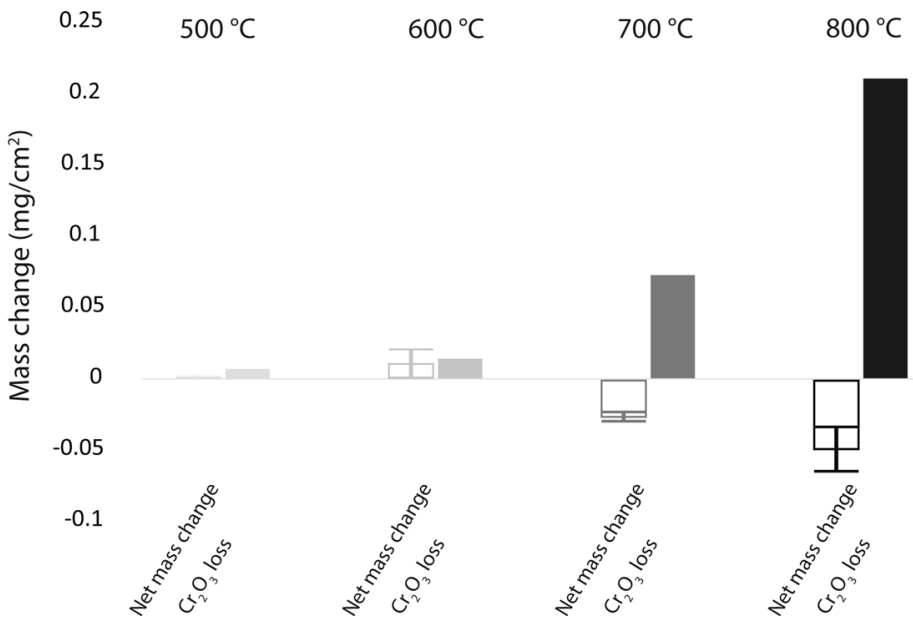

Fig. 1 Net mass change and $\mathrm{Cr}_{2} \mathrm{O}_{3}$ loss after $90 \mathrm{~h}$ exposure in air/20\% $\mathrm{H}_{2} \mathrm{O}$ (gas flow $1000 \mathrm{ml} / \mathrm{min}$ at $1 \mathrm{~atm}$ and $25^{\circ} \mathrm{C}$ ). The scatter between the triplicate samples is indicated

showed a mass loss at $700{ }^{\circ} \mathrm{C}$ and $800{ }^{\circ} \mathrm{C}$. Chromium volatilization (Reaction 1) increases rapidly with temperature. From 500 to $600{ }^{\circ} \mathrm{C}$, the amount of evaporation doubles; from 600 to $700{ }^{\circ} \mathrm{C}$, the increase is about five times and between 700 and $800{ }^{\circ} \mathrm{C}$ about three times. Figure 2 shows the time dependence of $\mathrm{Cr}$ evaporation at $600{ }^{\circ} \mathrm{C}, 700{ }^{\circ} \mathrm{C}$ and $800{ }^{\circ} \mathrm{C}$. In all cases, the rate of evaporation decreased with

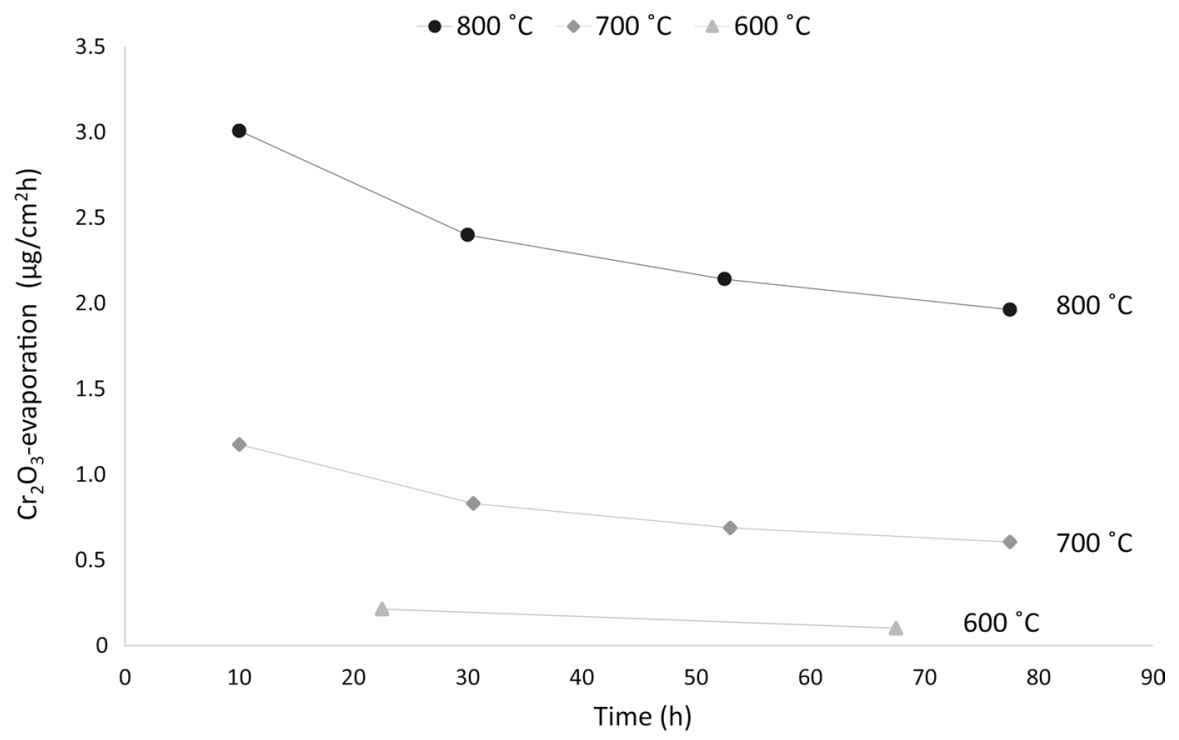

Fig. $2 \mathrm{Cr}_{2} \mathrm{O}_{3}$ evaporation rate in $90 \mathrm{~h}$ exposures in air/ $20 \% \mathrm{H}_{2} \mathrm{O}$ and a gas flow of $1000 \mathrm{ml} / \mathrm{min}$ at $1 \mathrm{~atm}$ and $25{ }^{\circ} \mathrm{C}$. Each denuder replacement is represented by a value, while the lines are for graphical illustration only 
exposure time. The chromium volatilization measurements can be re-calculated to vapour pressures, $\mathrm{P}\left(\mathrm{CrO}_{2}(\mathrm{OH})_{2}\right)$. Also, the corresponding equilibrium vapour pressure of $\mathrm{CrO}_{2}(\mathrm{OH})_{2}$ over $\mathrm{Cr}_{2} \mathrm{O}_{3}(\mathrm{~s})$ can be calculated using the $K_{p}$ values of Opila et al. [2]. As expected, the measured vapour pressures are lower than the equilibrium values. Thus, the highest values (corresponding to the first measurement points at 10 , respectively, $22.5 \mathrm{~h}$ ) corresponded to $9 \%$ of the equilibrium value at $600{ }^{\circ} \mathrm{C}$ and $37 \%$ at $800{ }^{\circ} \mathrm{C}$.

\section{Oxide Scale Characterization}

Figure 3 shows X-ray diffraction patterns from samples exposed for $90 \mathrm{~h}$ in air $+20 \% \mathrm{H}_{2} \mathrm{O}$ with a gas flow velocity $\leq 4 \mathrm{~cm} / \mathrm{s}$. After exposure at $500{ }^{\circ} \mathrm{C}, 600{ }^{\circ} \mathrm{C}$ and $700{ }^{\circ} \mathrm{C}$, corundum $\left(\alpha-\mathrm{M}_{2} \mathrm{O}_{3}\right)$ was the only phase detected, the intensity of the diffraction peaks increasing with temperature, presumably due to increasing scale thickness. After exposure at $800{ }^{\circ} \mathrm{C}$, the corundum-type oxide was accompanied by spinel oxide $\left(\mathrm{AB}_{2} \mathrm{O}_{4}\right)$.

XPS depth profiles from sample surface after $90 \mathrm{~h}$ at $600{ }^{\circ} \mathrm{C}, 700{ }^{\circ} \mathrm{C}$ and $800{ }^{\circ} \mathrm{C}$ are shown in Figs. 4, 5 and 6. The figures show the cation distribution at different depths (anions, i.e. oxygen, are excluded from the plots). After exposure at $600{ }^{\circ} \mathrm{C}$ (Fig. 4), most of the oxide scale was dominated by chromium, but nickel, iron and manganese were enriched close to the scale/gas interface. The nickel-, iron- and manganese-enriched region at the top of the scale was thicker at $700{ }^{\circ} \mathrm{C}$, but the elemental distribution was otherwise similar to that seen at $600{ }^{\circ} \mathrm{C}$ (Fig. 5). After exposure at $800{ }^{\circ} \mathrm{C}$ (Fig. 6), chromium was accompanied mainly by manganese and nickel in the outer part of the oxide scale. The chromium content increased with

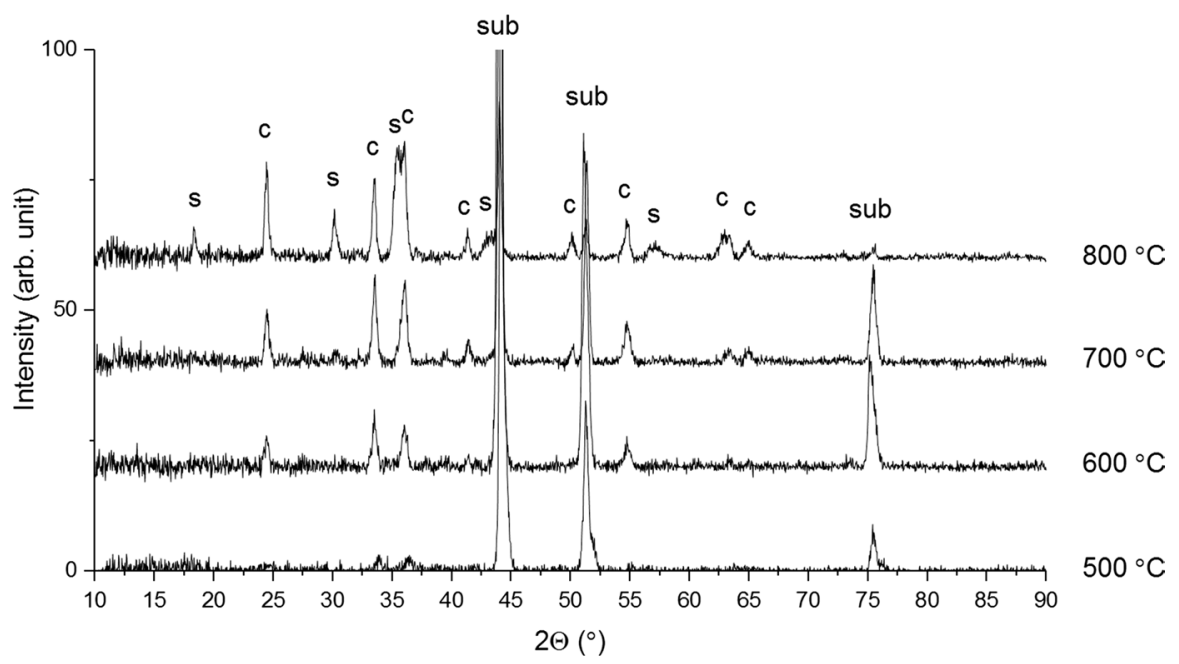

Fig. 3 XRD measurements from samples exposed for $90 \mathrm{~h}$ in air/20\% $\mathrm{H}_{2} \mathrm{O}$ and a gas flow of $1000 \mathrm{ml} /$ min at $1 \mathrm{~atm}$ and $25^{\circ} \mathrm{C}$. Metal matrix peaks are labelled (sub), corundum phase (c) and spinel phase (s) 
Fig. 4 XPS measurement from samples exposed for $90 \mathrm{~h}$ in air $/ 20 \% \mathrm{H}_{2} \mathrm{O}, 600{ }^{\circ} \mathrm{C}$ and a gas flow of $1000 \mathrm{ml} / \mathrm{min}$ at $1 \mathrm{~atm}$ and $25{ }^{\circ} \mathrm{C}$. Atomic concentrations are shown at different sputter times corresponding to different depths into the oxide scale. The lines show the threepoint average values, while the thin lines in the background are data from the measurement

Fig. 5 XPS measurement from samples exposed for $90 \mathrm{~h}$ in air $/ 20 \% \mathrm{H}_{2} \mathrm{O}, 700{ }^{\circ} \mathrm{C}$ and a gas flow of $1000 \mathrm{ml} / \mathrm{min}$ at $1 \mathrm{~atm}$ and $25{ }^{\circ} \mathrm{C}$. Atomic concentrations are shown at different sputter times corresponding to different depths into the oxide scale. The lines show the threepoint average values, while the thin lines in the background are data from the measurement
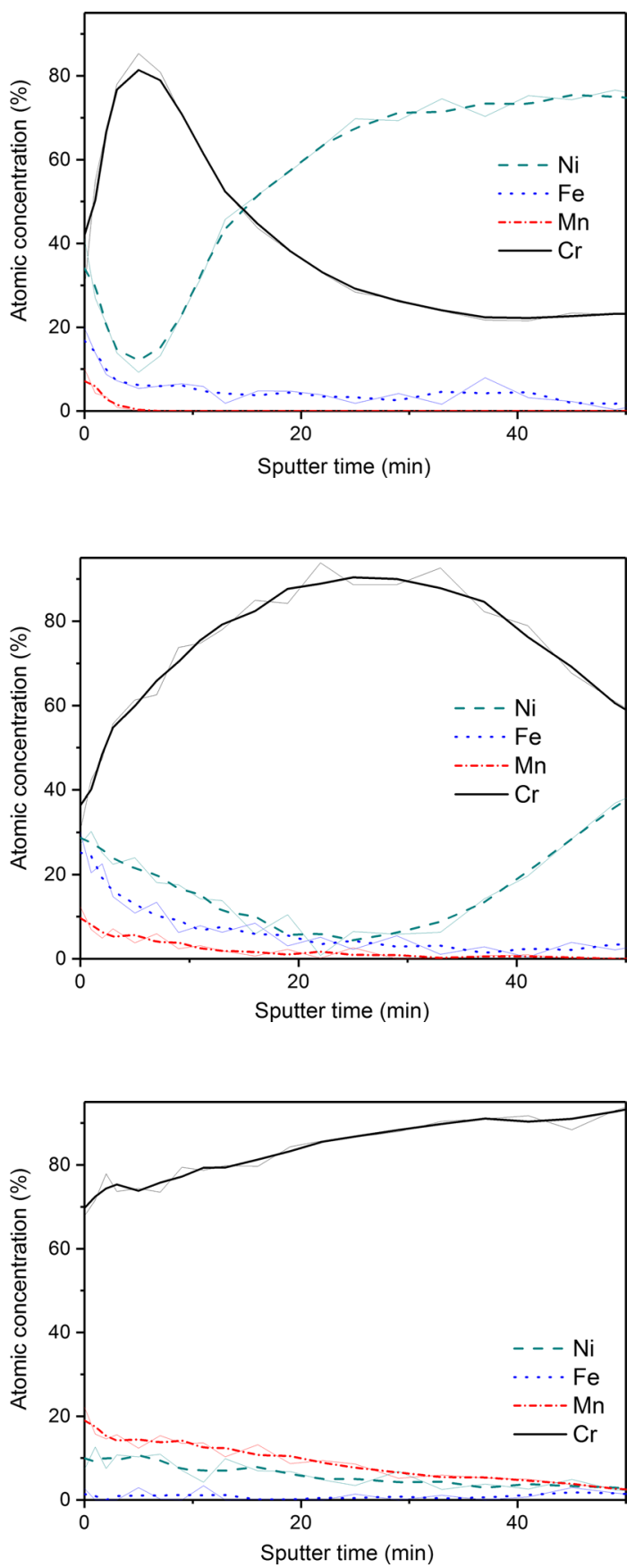

Sputter time $(\min )$
Fig. 6 XPS measurement from samples exposed for $90 \mathrm{~h}$ in air $/ 20 \% \mathrm{H}_{2} \mathrm{O}, 800{ }^{\circ} \mathrm{C}$ and a gas flow of $1000 \mathrm{ml} / \mathrm{min}$ at $1 \mathrm{~atm}$ and $25{ }^{\circ} \mathrm{C}$. Atomic concentrations are shown at different sputter times corresponding to different depths into the oxide scale. The lines show the threepoint average values, while the thin lines in the background are data from the measurement 


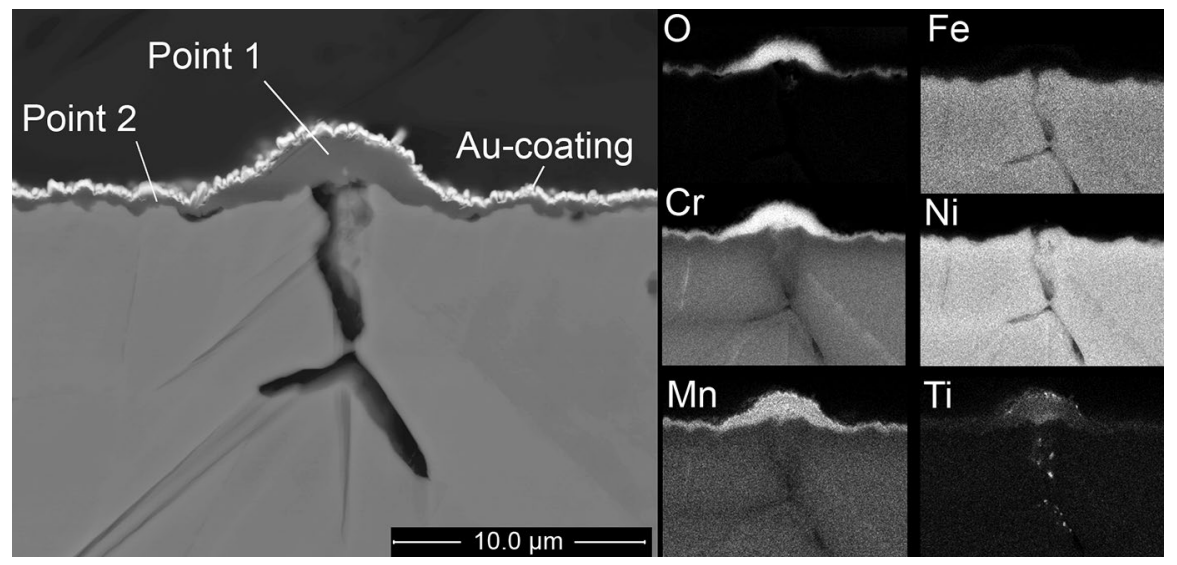

Fig. 7 SEM cross-sectional image showing oxide formed in exposure for $90 \mathrm{~h}$ in air $/ 20 \% \mathrm{H}_{2} \mathrm{O}$ at $800{ }^{\circ} \mathrm{C}$ and a gas velocity of $4.0 \mathrm{~cm} / \mathrm{s}$

Table 2 EDS point analyses of the oxide scale formed at low gas velocity $\left(800{ }^{\circ} \mathrm{C}, 20 \% \mathrm{H}_{2} \mathrm{O}\right.$, $90 \mathrm{~h}$ )

\begin{tabular}{lcc}
\hline Element & at.\% & at.\% \\
& Point 1 & Point 2 \\
\hline $\mathrm{O}$ & 58.2 & 46.3 \\
$\mathrm{Ti}$ & 1.1 & 0.5 \\
$\mathrm{Cr}$ & 38.0 & 37.8 \\
$\mathrm{Mn}$ & 0.9 & 3.8 \\
$\mathrm{Fe}$ & 0.3 & 2.1 \\
$\mathrm{Ni}$ & 1.3 & 9.3 \\
$\mathrm{Si}$ & 0.2 & 0.2 \\
\hline
\end{tabular}

The points analysed are indicated in Fig. 7

depth in the scale, the bottom part of the scale consisting of almost pure chromia (not shown in the figure).

A SEM cross-sectional image of the oxide scale formed at $800{ }^{\circ} \mathrm{C}$ after $90 \mathrm{~h}$ is shown in Fig. 7. Extensive void formation is observed along alloy grain boundaries in the subsurface region. The oxide scale above these voids is significantly thicker than the scale formed on the interior of the grains. The thickness of the oxide scale is estimated to be around $1.5 \mu \mathrm{m}$ at the grain boundaries and $0.5 \mu \mathrm{m}$ on the grain interiors. EDS point analyses were performed on the two types of scales, revealing differences in the chemical composition (Table 2). It should be noted that the EDS analysis of the thin oxide on the grain interiors also probes the underlying metal. While both types of oxide scales are dominated by chromium, the oxide scale above the interior of the alloy grains (Point 2) is higher in manganese. In contrast, titanium enrichments were observed close to the alloy grain boundary, the cavity in the former alloy grain boundary region showing titanium-rich particles. 


\section{Influence of Flow Rate on Chromium Volatilization and Scale Morphology (20\% $\mathrm{H}_{2} \mathbf{0}, 800^{\circ} \mathrm{C}$ )}

\section{Chromium-oxy-hydroxide Evaporation}

To investigate the effect of the rate of chromium volatilization on corrosion behaviour and scale morphology at constant temperature and gas composition, corrosion exposures were performed at different gas flow rates, corresponding to different net gas velocities in the furnace tube. Figure 8 shows the change in sample mass and the accumulated chromium volatilization after $200 \mathrm{~h}$ exposure to air $/ 20 \% \mathrm{H}_{2} \mathrm{O}$ at $800{ }^{\circ} \mathrm{C}$ at four different net gas velocities: $4.0 \mathrm{~cm} / \mathrm{s}, 11.8 \mathrm{~cm} / \mathrm{s}$, $23.7 \mathrm{~cm} / \mathrm{s}$ and $31.6 \mathrm{~cm} / \mathrm{s}$. As expected, chromium volatilization increases with increasing gas velocity. Increasing the net gas velocity from 4.0 to $11.8 \mathrm{~cm} / \mathrm{s}$ resulted in an increase in chromium-oxy-hydroxide evaporation of about $20 \%$. Increasing the net gas velocity from 11.8 to $23.7 \mathrm{~cm} / \mathrm{s}$ increased the chromium volatilization by about $30 \%$, and an increase from 23.7 to $31.6 \mathrm{~cm} / \mathrm{s}$ increased the volatilization further by about $20 \%$. Sample mass loss also increased with the net gas velocity up to $23.7 \mathrm{~cm} / \mathrm{s}$. However, the mass losses recorded at $23.7 \mathrm{~cm} / \mathrm{s}$ and $31.6 \mathrm{~cm} / \mathrm{s}$ gas velocity were indistinguishable, given the experimental scatter. The time dependence of the chromium volatilization rates during the $200 \mathrm{~h}$ exposures is presented in Fig. 9. The results show that the rate of chromium volatilization depends strongly on gas velocity in the beginning of the exposures, but that this dependence becomes weaker with time, the four curves tending to converge towards the end of the exposure. Note that after $>150 \mathrm{~h}$, chromium-oxy-hydroxide evaporation was slightly lower in the $31.6 \mathrm{~cm} / \mathrm{s}$ exposure than in the $23.7 \mathrm{~cm} / \mathrm{s}$ experiment. As the flow rate is increased, Reaction (1) is expected to be pushed

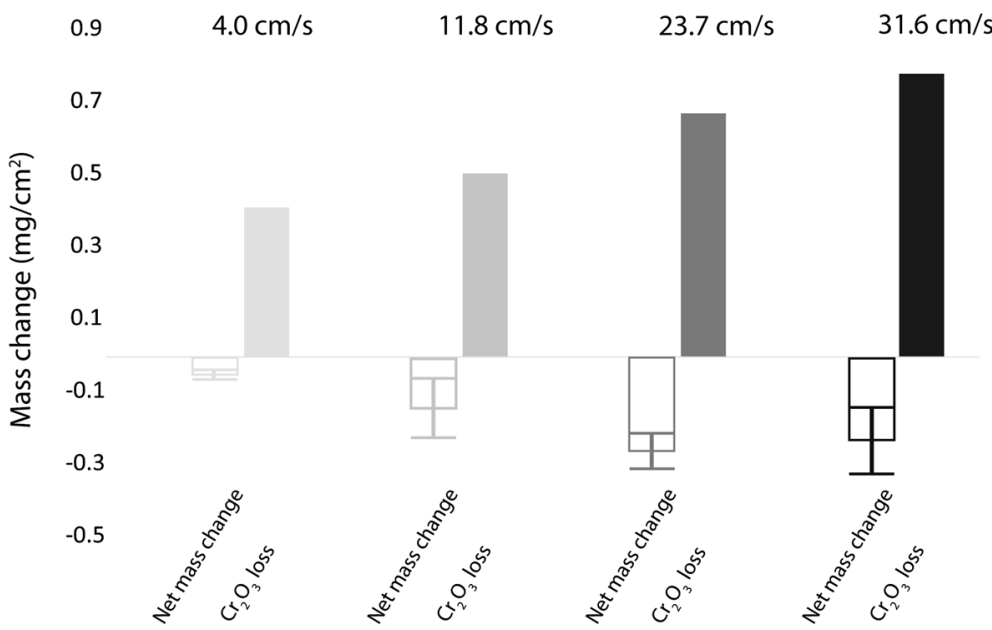

Fig. 8 Net mass change and accumulated $\mathrm{Cr}_{2} \mathrm{O}_{3}$ evaporation after $200 \mathrm{~h}$ exposures in air/20\% $\mathrm{H}_{2} \mathrm{O}$ at $800{ }^{\circ} \mathrm{C}$ and gas flow rates of $4.0 \mathrm{~cm} / \mathrm{s}, 11.8 \mathrm{~cm} / \mathrm{s}, 23.7 \mathrm{~cm} / \mathrm{s}$ and $31.6 \mathrm{~cm} / \mathrm{s}$. The scatter between the triplicate samples is indicated 


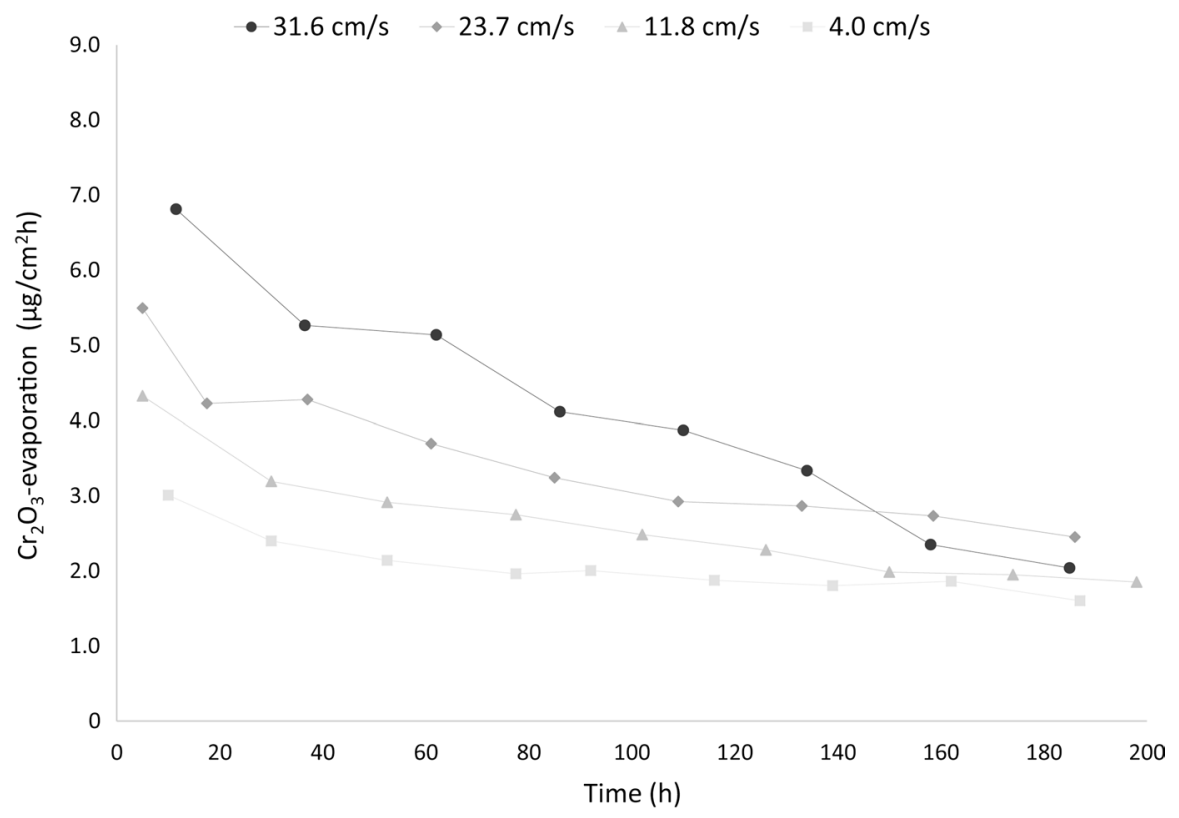

Fig. $9 \mathrm{Cr}_{2} \mathrm{O}_{3}$ evaporation rate in $200 \mathrm{~h}$ exposures in air/ $20 \% \mathrm{H}_{2} \mathrm{O}$ at $800{ }^{\circ} \mathrm{C}$ with different gas flow velocities. Each denuder replacement is represented by a value, while the lines are for graphical illustration only

further from its equilibrium. Accordingly, the maximum measured $\mathrm{P}\left(\mathrm{CrO}_{2}(\mathrm{OH})_{2}\right.$ values decrease with increasing flow rate.

\section{Oxide Scale Characterization}

Figure 10 shows photographic images of the sample coupons after $200 \mathrm{~h}$ exposure at $800{ }^{\circ} \mathrm{C}$ in air $/ 20 \% \mathrm{H}_{2} \mathrm{O}$ at different gas velocities. At the lowest gas velocity of $4.0 \mathrm{~cm} / \mathrm{s}$, the entire sample is dark. At higher flow velocities, the top part of the samples shows a bright contrast, while the bottom part of the samples (the part closest to the alumina sample holder) remains dark. There is also an increased tendency for the leading edge of the sample to form bright areas. The two distinctively different areas are hereafter referred to as "dark area" and "bright area", respectively. It is noted that the extent of the bright area increases with increasing gas velocity. Figure 10 also shows a SEM plan view image of the region indicated by a square on the sample image on the right-hand side, corresponding to the border between the bright area and the dark area.

Figure 11 shows a SEM cross-sectional image of the dark area from the exposure at $31.6 \mathrm{~cm} / \mathrm{s}$. In this area, the oxide scale on the interior of the alloy grain is about $0.5 \mu \mathrm{m}$ thick, while the scale in the vicinity of the alloy grain boundaries is about $1.5 \mu \mathrm{m}$. EDS analyses of the points indicated in Fig. 11 are presented in Table 3 and shows that the oxide is very rich in chromium and contains small amounts of impurities, mainly manganese. The oxides present at the alloy grain 
Gas flow direction

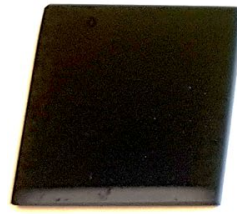

$4.0 \mathrm{~cm} / \mathrm{s}$

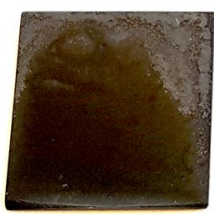

$11.8 \mathrm{~cm} / \mathrm{s}$

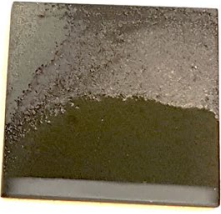

$23.7 \mathrm{~cm} / \mathrm{s}$

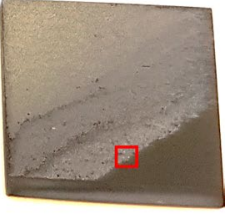

$31.6 \mathrm{~cm} / \mathrm{s}$

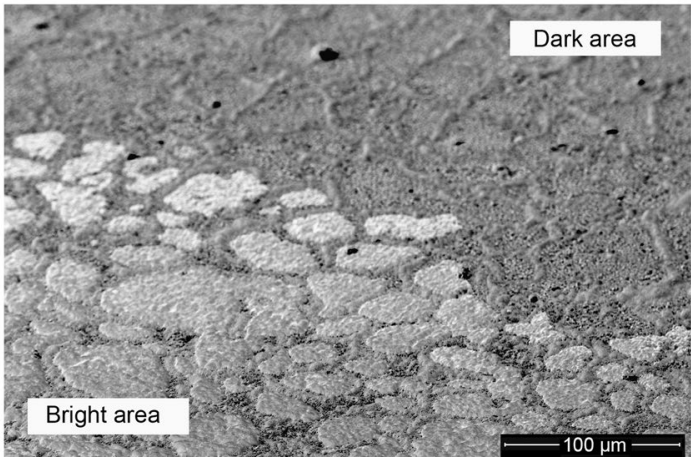

Fig. 10 Photographs showing samples after exposure for $200 \mathrm{~h}$ in air/20\% $\mathrm{H}_{2} \mathrm{O}$ at $800{ }^{\circ} \mathrm{C}$ and different gas flow velocities. The gas flow direction during the exposure is indicated. The image below shows a SEM top view image of the border between the "bright area" and the "dark area"

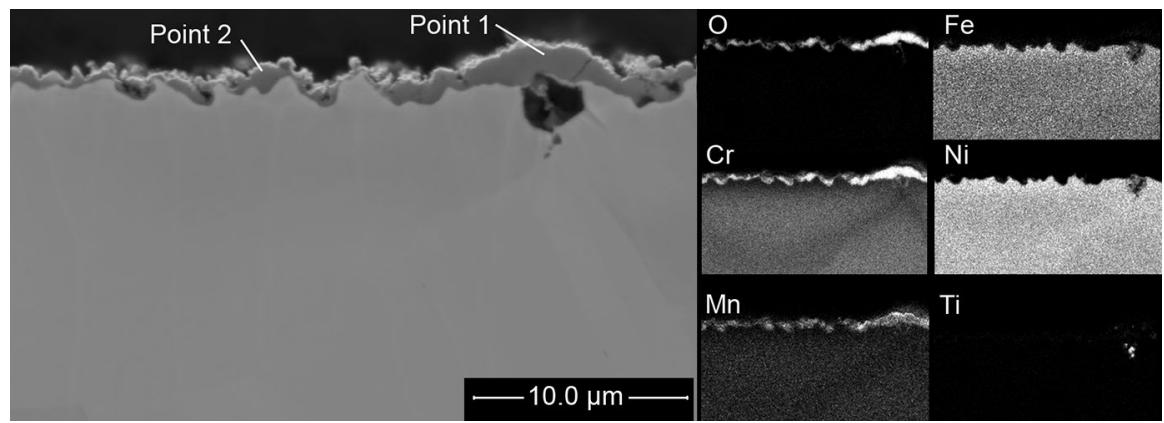

Fig. 11 SEM cross-sectional image showing the oxide scale in the dark area after exposure for $200 \mathrm{~h}$ in air $/ 20 \% \mathrm{H}_{2} \mathrm{O}$ at $800{ }^{\circ} \mathrm{C}$ and a gas flow velocity of $31.6 \mathrm{~cm} / \mathrm{s}$

boundaries and on the grain interior have similar composition, except that the oxide on the grain interior is higher in manganese. There is a cavity in the substrate at an alloy grain boundary, similar to that shown in Fig. 7, containing titanium oxide particles along edges. 
Table 3 EDS point analyses of the oxide scale in the dark area $\left(800{ }^{\circ} \mathrm{C}, 20 \% \mathrm{H}_{2} \mathrm{O}, 200 \mathrm{~h}\right.$, high gas velocity)

Table 4 EDS analysis of point indicated in Fig. $12\left(800{ }^{\circ} \mathrm{C}\right.$, $20 \% \mathrm{H}_{2} \mathrm{O}, 200 \mathrm{~h}$, high gas velocity)

\begin{tabular}{lcc}
\hline Element & at.\% & at.\% \\
& Point 1 & Point 2 \\
\hline $\mathrm{O}$ & 56.3 & 54.3 \\
$\mathrm{Al}$ & 0.1 & 0.2 \\
$\mathrm{Cr}$ & 41.8 & 42.3 \\
$\mathrm{Mn}$ & 1.1 & 1.7 \\
$\mathrm{Fe}$ & 0.2 & 0.3 \\
$\mathrm{Ni}$ & 0.5 & 1.2 \\
\hline
\end{tabular}

The points analysed are indicated in Fig. 11

\begin{tabular}{lr}
\hline Element & at.\% \\
\hline $\mathrm{O}$ & 46.1 \\
$\mathrm{Al}$ & 0.3 \\
$\mathrm{Cr}$ & 2.8 \\
$\mathrm{Mn}$ & 0.7 \\
$\mathrm{Fe}$ & 4.3 \\
$\mathrm{Ni}$ & 45.8 \\
\hline
\end{tabular}

The SEM cross-sectional examination of the bright area in Fig. 12 shows a morphology and composition of the oxide scale that is very different from that in the dark area. In the bright area, the oxide scale is multilayered and features a top part which is rich in nickel and almost completely depleted in chromium. The EDS point analysis in Table 4 indicates that this part of the scale mainly consists of nickel-rich oxide. Beneath the top layer, there is an intermediate region of the oxide scale with varying composition, featuring local enrichments

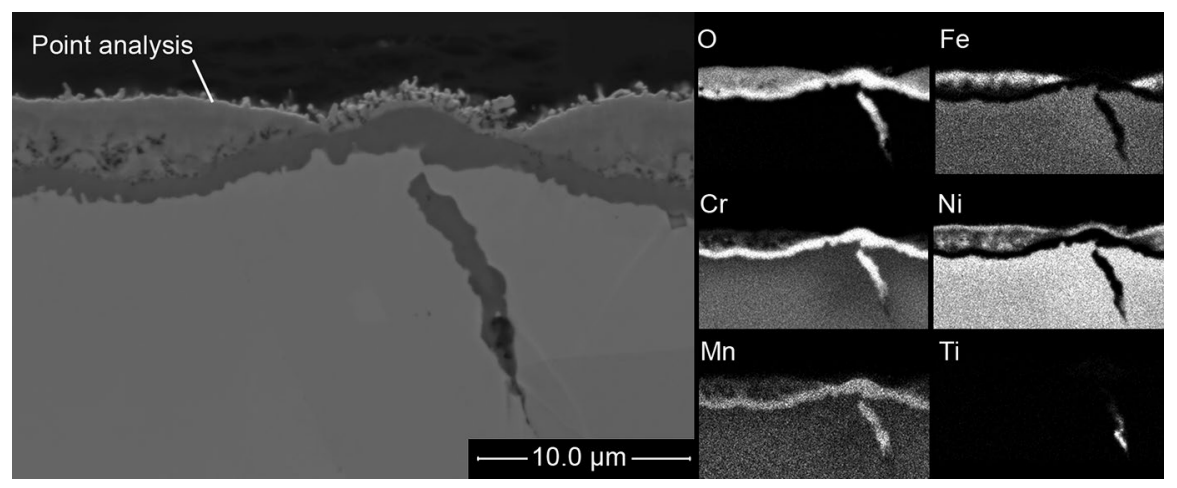

Fig. 12 SEM cross-sectional image showing the oxide scale in the bright area after exposure for $200 \mathrm{~h}$ in air $/ 20 \% \mathrm{H}_{2} \mathrm{O}$ at $800{ }^{\circ} \mathrm{C}$ and a gas flow velocity of $31.6 \mathrm{~cm} / \mathrm{s}$ 


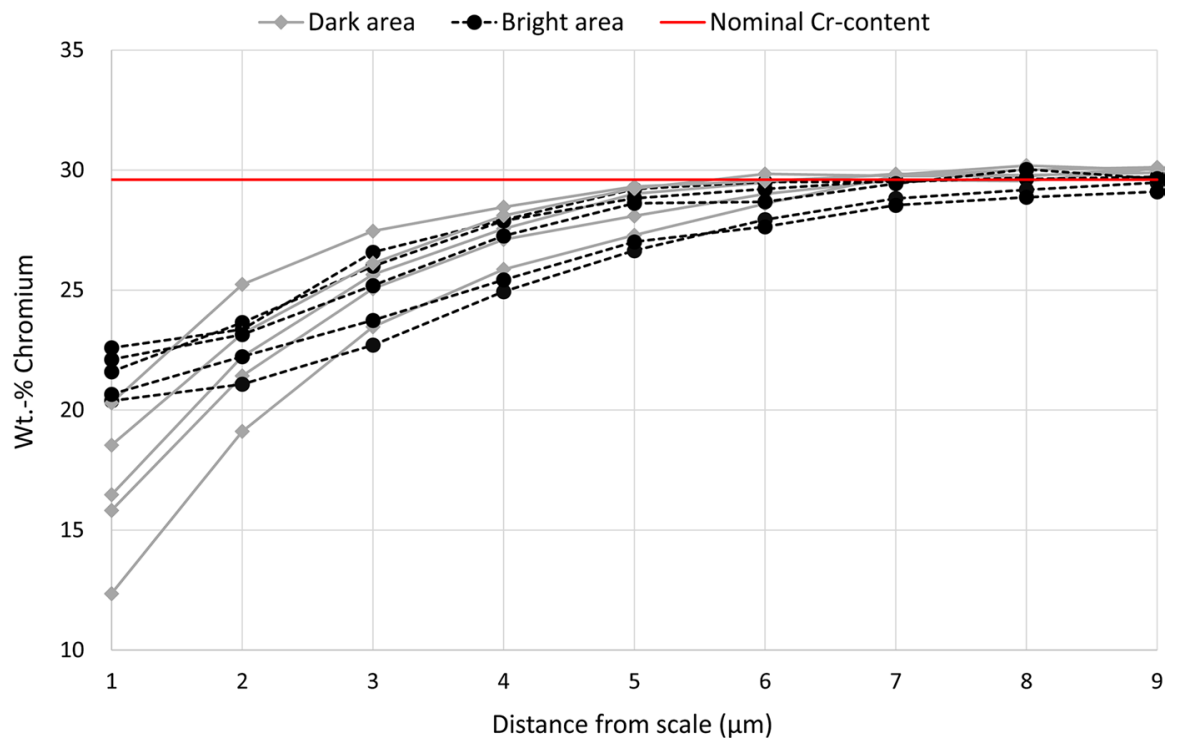

Fig. 13 Chromium depletion profiles measured by EDS from scale/metal interface into the metal matrix in the bright area and in the dark area after exposure for $200 \mathrm{~h}$ in air $/ 20 \% \mathrm{H}_{2} \mathrm{O}$ at $800{ }^{\circ} \mathrm{C}$ and a gas flow velocity of $31.6 \mathrm{~cm} / \mathrm{s}$

of iron, nickel, chromium and manganese. The thickness of the top and intermediate layers is about $0.4 \mu \mathrm{m}$ and $3 \mu \mathrm{m}$, respectively. In the bottom part of the scale, close to the metal/oxide interface, a continuous chromium-rich oxide is observed with a thickness of about $1 \mu \mathrm{m}$. The scale formed at the alloy grain boundaries is somewhat different in that the intermediate layer is absent, while the nickel-rich top layer is thinner and sometimes gives way to Ni-rich oxide nodules sitting on top of the Cr-rich oxide in the bottom of the scale. Figure 13 shows the chromium concentration in the alloy substrate as a function of the distance to the oxide/alloy interface for both dark and bright regions. The metal grains were randomly chosen. In the bright area, the chromium depletion profile is shallow, reaching minimum values of $20-23 \mathrm{wt} \%$ chromium at the metal/ oxide interface. The chromium-depleted zone reaches about $6 \mu \mathrm{m}$ into the grains where the bulk value of $29 \mathrm{wt} \%$ is measured. In the dark area, the chromium gradient is steeper with a minimum chromium concentration of $12-20 \mathrm{wt} \%$ chromium at the metal/oxide interface.

\section{Proof of Concept}

The observation that the conditions which initially resulted in the fastest chromium volatilization also resulted in the formation of a scale featuring a Ni-rich cap layer separating the inner, more chromium-rich parts of the oxide scale from the gas, suggesting that this effect may be used for decreasing chromium volatilization. 

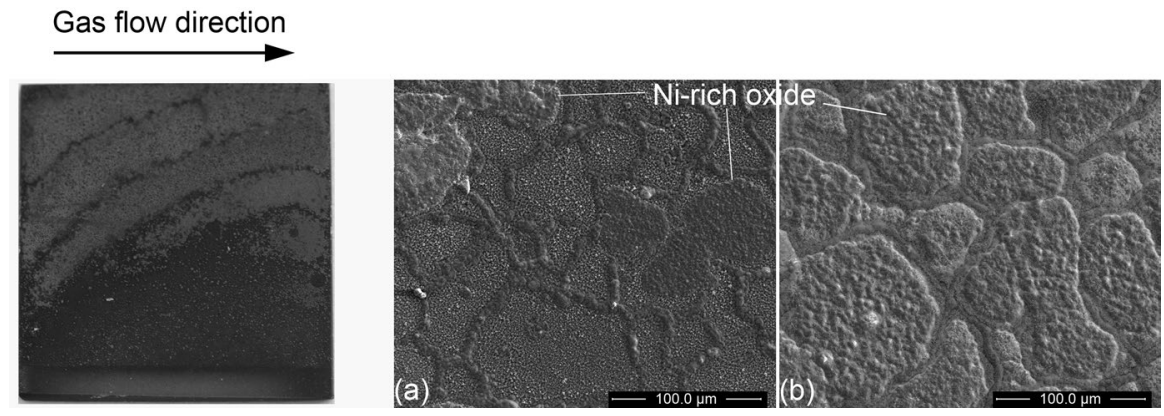

Fig. 14 Left image shows a sample after exposure for $200 \mathrm{~h}$ in air $/ 42 \% \mathrm{H}_{2} \mathrm{O}$ at $800{ }^{\circ} \mathrm{C}$ and gas flow velocity of $11.8 \mathrm{~cm} / \mathrm{s}$. The SEM top view images to the right show the dark area (a) and the bright area (b)

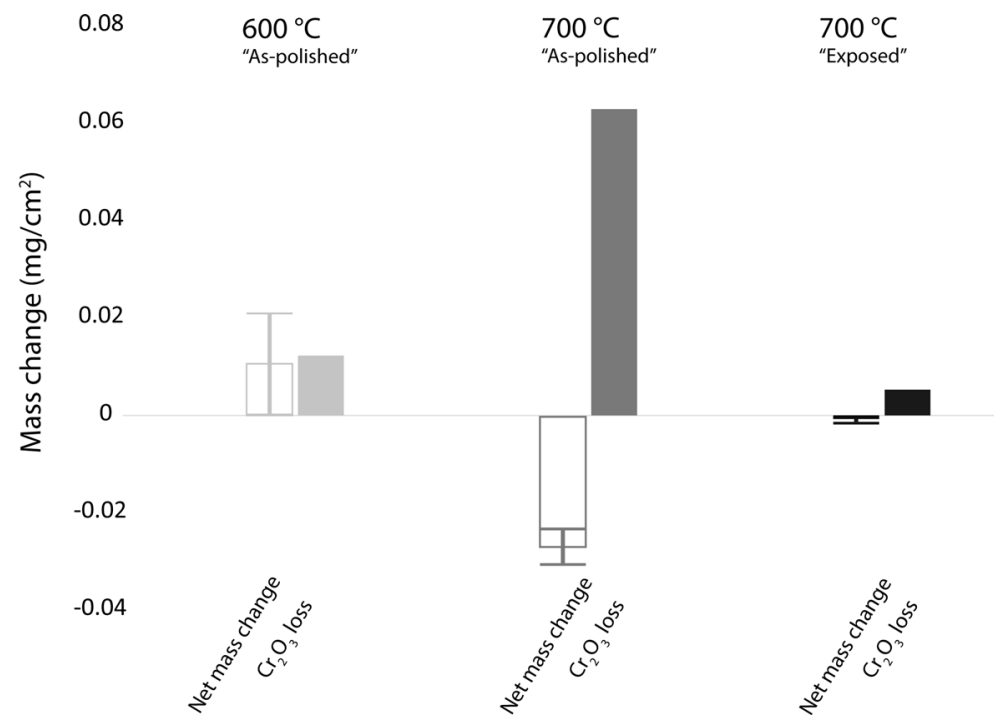

Fig. 15 Net mass changes and $\mathrm{Cr}_{2} \mathrm{O}_{3}$ loss after $90 \mathrm{~h}$ exposure of as-exposed samples in air/20\% $\mathrm{H}_{2} \mathrm{O}$ at $700{ }^{\circ} \mathrm{C}$ and a gas flow velocity of $3.6 \mathrm{~cm} / \mathrm{s}$ compared to results from Fig. 1 . The scatter between the triplicate samples is indicated

Samples exposed in air $/ 42 \% \mathrm{H}_{2} \mathrm{O}$ at $800{ }^{\circ} \mathrm{C}$ and a gas velocity of $11.8 \mathrm{~cm} / \mathrm{s}$ for $200 \mathrm{~h}$ showed a similar drop in chromium evaporation and a similar oxide morphology as in air/20\% $\mathrm{H}_{2} \mathrm{O}$ with gas velocity of $31.6 \mathrm{~cm} / \mathrm{s}$ for $200 \mathrm{~h}$ (Fig. 14). For these samples, $60-70 \%$ of the coupons' surface exhibited the bright area surface condition corresponding to the scale having a top Ni-rich cap layer. These samples were used in a proof-of-concept experiment in which there was an exposure for an additional $90 \mathrm{~h}$ in air $/ 20 \% \mathrm{H}_{2} \mathrm{O}$ at $700{ }^{\circ} \mathrm{C}$ at a gas velocity of $3.6 \mathrm{~cm} / \mathrm{s}$, i.e. conditions similar to the experiments in Fig. 1. Figure 15 shows the chromium volatilization and net mass changes for these samples and the corresponding values for as-polished 
samples exposed at $600{ }^{\circ} \mathrm{C}$ and $700{ }^{\circ} \mathrm{C}$. The results show a dramatic decrease in chromium volatilization (about $91 \%$ ) for the as-exposed compared to the as-polished sample. Also, the as-exposed samples showed a small net mass loss (7\% of the value recorded for the as-polished sample), showing that the rate of oxidation is also slow.

\section{Discussion}

Exposing alloy 690 to $\mathrm{H}_{2} \mathrm{O}$ /air mixtures in the temperature range $500-800{ }^{\circ} \mathrm{C}$ results in two clearly distinguishable corrosion modes, depending on the initial rate of chromium evaporation. The two corrosion modes differ with respect to both oxidation morphology and chromium volatilization behaviour.

1. At $500-700{ }^{\circ} \mathrm{C}$, the entire scale consists of corundum-type chromium-rich oxide containing small amounts of iron, nickel and manganese. Chromium-oxy-hydroxide volatilization decreases slowly with time.

2. Under harsher conditions, i.e. at $800{ }^{\circ} \mathrm{C}$ and high gas velocity, another type of scale emerges that appears bright both in SEM and by the naked eye (Fig. 10). Chromium volatilization is initially very fast but decreases rapidly with time. In the bright area, the bottom part of the oxide scale consists of chromia, while the top of the scale is essentially chromium free, consisting of Ni-rich oxide. The "bright" scale only covers part of the surface, the bright scale area fraction rising with increasing gas velocity. The remainder of the surface is dark and has a scale morphology similar to that described under 1.

The present study shows that subjecting alloy 690 to conditions that initially cause very fast chromium vaporization $\left(800{ }^{\circ} \mathrm{C}\right.$ and high gas velocity) triggers the formation of a scale consisting of a bottom chromia layer and a top layer that are almost $\mathrm{Cr}$ free and very rich in $\mathrm{Ni}$. Thus, the EDX elemental maps show very low levels of chromium at the scale surface in all areas that appear bright in the SEM images, cf. Figure 12. The chromium depletion of the scale surface in the bright areas is much more extensive than what is reported for $\mathrm{MnCr}_{2} \mathrm{O}_{4} / \mathrm{Cr}_{2} \mathrm{O}_{3}$ scales on ferritic stainless steels subjected to chromium vaporization [12-14]. The steep drop in the rate of chromium volatilization with time (Fig. 9) correlates with the appearance of the bright area, implying that the Ni-rich surface layer is very effective in suppressing chromium volatilization due to limiting the availability of chromia at the scale surface which is necessary for $\mathrm{CrO}_{2}(\mathrm{OH})_{2}$ formation (Reaction 1). While $\mathrm{NiO}$ is known to volatilize as $\mathrm{Ni}(\mathrm{OH})_{2}$ in the presence of water vapour at high temperatures [21], the equilibrium vapour pressure of $\mathrm{Ni}(\mathrm{OH})_{2}$ over $\mathrm{NiO}$ is calculated to be three orders of magnitude less than for $\mathrm{CrO}_{2}(\mathrm{OH})_{2}$ over $\mathrm{Cr}_{2} \mathrm{O}_{3}$ under our experimental conditions $\left(800{ }^{\circ} \mathrm{C}\right.$, air with $\left.20 \mathrm{vol} \% \mathrm{H}_{2} \mathrm{O}\right)$. Thus, $\mathrm{Ni}(\mathrm{OH})_{2}$ volatilization is considered insignificant. The high efficiency of this characteristic scale morphology in diminishing chromium volatilization was demonstrated by first exposing samples in an environment causing severe chromium evaporation, resulting in a surface partially covered by Ni-rich oxide, and 
subsequently exposing the same samples at $700{ }^{\circ} \mathrm{C}$ for $90 \mathrm{~h}$. The $800{ }^{\circ} \mathrm{C}$ pre-oxidation treatment resulted in a $90 \%$ reduction in chromium evaporation compared to the corresponding $700{ }^{\circ} \mathrm{C}$ exposure of as-polished samples (Fig. 15). The scale present on the remaining dark areas on the samples exposed under "harsh" conditions is similar to the scale formed at 500-700 ${ }^{\circ} \mathrm{C}$, exhibiting chromium-rich oxides at the top of the scale. It is argued that this scale morphology supports a rapid chromium volatilization, explaining the extensive chromium depletion of the substrate (Fig. 13).

It is argued that the severe Cr depletion in the subsurface region of the dark area precedes a breakdown of the initial chromia scale which then leads to a secondary oxide formation that, in turn, gives rise to the Ni-rich surface layer. Thus, exposing alloy 690 to dry air at $500-800{ }^{\circ} \mathrm{C}$ is expected to result in formation of chromia-rich protective scales accompanied by minimal nickel oxidation, except for the initial, transient stage. This prediction is in line with the present results from the exposures at $500-700{ }^{\circ} \mathrm{C}$ (Fig. 7) and for the remaining dark area on the samples exposed at $800{ }^{\circ} \mathrm{C}$ and high gas velocity (Fig. 11). The large amount of $\mathrm{Ni}^{2+}$ detected in the top part of the scale in the bright area therefore cannot be attributed to initial, transient oxidation, implying that nickel in the substrate beneath the bright area is being oxidized.

It is suggested that this behaviour is due to the rapid chromium volatilization from the scale surface which has caused the alloy substrate to become so strongly depleted in chromium (Fig. 13) that it is no longer able to supply enough chromium to the scale/alloy interface to sustain the selective oxidation of chromium. The alloy thus goes into another oxidation mode, forming an oxide scale containing large amounts of nickel together with some chromium and iron. Figure 16 schematically describes the evolution of the oxide scale in this scenario. Figure 16a corresponds to the chromia-rich protective scale that forms initially on alloy 690 under the present exposure conditions. It is the only scale morphology observed at 500-700 ${ }^{\circ} \mathrm{C}$ (Fig. 7), and it also applies to the remaining dark area on the samples exposed at high flow velocities at $800{ }^{\circ} \mathrm{C}$ (Fig. 11). The chromia scale in the remaining dark area is quite thin (compare Point 2 in

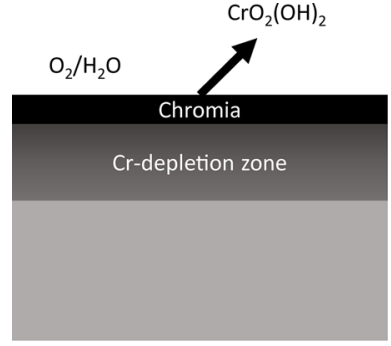

(a)

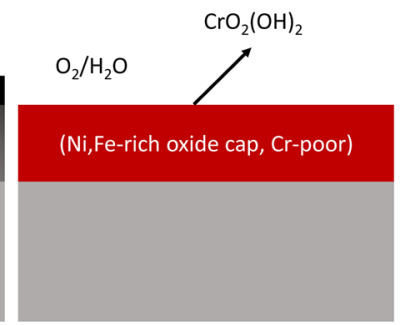

(b)

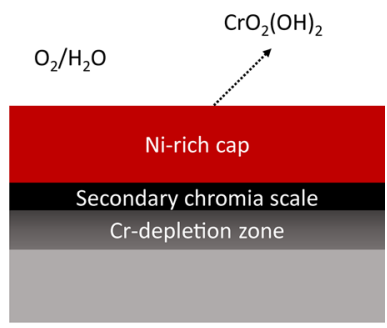

(c)

Fig. 16 Schematic figure showing the proposed oxidation mechanisms. In step a the initial chromia is evaporated with $\mathrm{Cr}$ depletion of the alloy substrate as a consequence, in $\mathbf{b}$ the breakdown of the chromia layer occur leading to oxidation of nickel and iron, reducing Cr evaporation, in $\mathbf{c}$ the Ni-rich cap layer is established minimizing $\mathrm{Cr}$ evaporation so that a secondary chromia scale can form 
Fig. 11). Figure $16 \mathrm{~b}$ corresponds to the situation when the selective oxidation of chromium has ceased. Oxidation of the severely Cr-depleted substrate is now accompanied by formation of a scale consisting of a mixture of nickel, chromium and iron oxides, presumably including spinel oxides $\left(\mathrm{M}_{3} \mathrm{O}_{4}\right)$. Because of the continued chromium volatilization, the top part of the mixed oxide scale is converted into a Ni-rich and Cr-poor cap oxide that effectively suppresses the chromium volatilization. The resulting decreased flux of chromium from the underlying metal allows the chromium level in the substrate to recover (compare Fig. 13) to a degree that enables the formation of a secondary protective chromia layer at the scale/alloy interface. The resulting new scale morphology is depicted in $16 \mathrm{c}$, corresponding to the bright scale formed under high gas velocity at $800{ }^{\circ} \mathrm{C}$ (Fig. 10).

The formation of a Ni-Cr-Fe mixed oxide scale in this scenario (Fig. 16b) is in line with the oxidation behaviour of alloy 600 [6], alloy 600 being similar to alloy 690, except for its lower chromium content (14-17 wt\% and 27-31 wt\%, respectively). It may be noted that a chromium content of about $20 \mathrm{wt} \%$ is reportedly needed in order for nickel-base alloys to form a protective chromia scale in the temperature range studied [22].

The beneficial oxidation behaviour of alloy 690 under harsh conditions, combining the presence of a slow-growing chromia layer and a Ni-rich cap oxide that restricts chromium volatilization, is thus attributed to an initial chromium depletion of the substrate that triggers the formation of a $\mathrm{Ni}$-rich oxide scale that suppresses the chromium volatilization and allows a secondary chromia scale to form. The ability to form a secondary chromia scale under these harsh conditions is connected to the very high chromium concentrations of alloy 690. For example, in the case of alloy 600, the material remains in stage b in Fig. 16).

The rapid chromium depletion sustained under "harsh" conditions is accompanied by the formation of large voids at the alloy grain boundaries (see Figs. 7 and 11). It is well known that grain boundaries in alloys constitute rapid diffusion paths for atoms [23]. Indeed, the rapid flux of chromium atoms towards the alloy/oxide interface along the grain boundaries is evidenced by elemental mapping (Fig. 11) and is suggested to cause the cavities observed. The oxide scale covering the voids at the grain boundaries is thicker than on the grain interiors. The influence of the alloy microstructure on the scale morphology and the $\mathrm{CrO}_{2}(\mathrm{OH})_{2}$ volatilization behaviour of alloy 690 will be addressed in a separate paper.

The bright contrast areas observed under high gas velocities at $800{ }^{\circ} \mathrm{C}$ show a characteristically uneven distribution (Fig. 10), bright areas dominating at the top of the samples and to some extent along the edges, while dark areas predominate in the bottom part. This is clearly the effect of the gas flow pattern at the sample surface, which in turn influences the rate of chromium volatilization. Laminar flow conditions prevail in all experiments, meaning that the gas velocity is at a maximum along the central line of the furnace tube. Hence, the part of the sample close to the sample holder will experience lower gas velocities, which in turn is expected to result in an (initially) slower chromium volatilization. This is suggested to explain why the part of the sample close to the sample 
holder tends to be darker (see the bottom of the samples in Figs. 10 and 14). The tendency for the bright areas to be more dominant at the sample leading edge is attributed to the development of the gas boundary layer along the sample surface, the part of the sample with the thinnest gas boundary layer suffering the fastest chromium volatilization.

\section{Conclusions}

- Exposing alloy 690 to $\mathrm{H}_{2} \mathrm{O} /$ air mixtures in the temperature range $500-800{ }^{\circ} \mathrm{C}$ results in two different corrosion modes, depending on temperature and gas velocity.

- At $500-700{ }^{\circ} \mathrm{C}$, the entire scale consists of corundum-type chromium-rich oxide, the volatilization of $\mathrm{CrO}_{2}(\mathrm{OH})_{2}$ decreasing slowly with time.

- At $800{ }^{\circ} \mathrm{C}$ and high gas velocity, chromium volatilization is initially very fast but decreases rapidly with time. The oxide scale forms a surface layer that is essentially chromium free, consisting of nickel-rich oxide.

- The latter corrosion morphology appears because rapid chromium volatilization renders the protective chromia layer unstable, causing it to be replaced by an oxide scale containing large amounts of nickel together with chromium and iron. The continued rapid loss of chromia from this "new" mixed oxide scale produces the Ni-rich Cr-depleted cap layer.

- Formation of the Ni-rich cap layer greatly decreases the chromium volatilization, resulting in a recovery of the chromium levels in the substrate and allowing a protective chromia layer to form again, in the bottom of the scale.

- The ability of alloy 690 to "re-passivate" after the initial breakdown of the protective scale implies that its oxidation properties can be improved by a pre-treatment that allows the Ni-rich cap layer to form. Thus, the cap layer protects the alloy from being Cr-depleted and mitigates problems associated with the release of hexavalent chromium species. The practicality of this approach is illustrated.

Acknowledgments Open access funding provided by Chalmers University of Technology. This work was carried out at the Swedish High Temperature Corrosion Centre (HTC) together with the Department of Industrial and Materials Science at Chalmers University and within the strategic innovation programme "Metalliska material", a joint programme by Vinnova, Formas and the Swedish Energy Agency.

Open Access This article is distributed under the terms of the Creative Commons Attribution 4.0 International License (http://creativecommons.org/licenses/by/4.0/), which permits unrestricted use, distribution, and reproduction in any medium, provided you give appropriate credit to the original author(s) and the source, provide a link to the Creative Commons license, and indicate if changes were made. 


\section{References}

1. H. Asteman, J. E. Svensson, L. G. Johansson and M. Norell, Indication of Chromium Oxide Hydroxide Evaporation During Oxidation of 304L at $873 \mathrm{~K}$ in the Presence of $10 \%$ Water Vapor. Oxidation of Metals 52, 95 (1999).

2. E. J. Opila, D. J. Myers, N. S. Jacobson, et al., Theoretical and Experimental Investigation of the Thermochemistry of $\mathrm{CrO}_{2}(\mathrm{OH})_{2}(\mathrm{~g})$. The Journal of Physical Chemistry A 111, 1971 (2007).

3. B. B. Ebbinghaus, Thermodynamics of gas phase chromium species: The chromium oxides, the chromium oxyhydroxides, and volatility calculations in waste incineration processes. Combustion and Flame 93, 119 (1993).

4. B. Pujilaksono, T. Jonsson, H. Heidari, et al., Oxidation of Binary FeCr Alloys (Fe-2.25Cr, Fe-10Cr, $\mathrm{Fe}-18 \mathrm{Cr}$ and $\mathrm{Fe}-25 \mathrm{Cr}$ ) in $\mathrm{O}_{2}$ and in $\mathrm{O}_{2}+\mathrm{H}_{2} \mathrm{O}$ Environment at $600{ }^{\circ} \mathrm{C}$. Oxidation of Metals 75, 183 (2011).

5. V. P. Deodeshmukh, Long-Term Performance of High-Temperature Foil Alloys in Water Vapor Containing Environment. Part I: Oxidation Behavior. Oxidation of Metals 79, 567 (2013).

6. J. Xiao, N. Prud'homme, N. Li and V. Ji, Influence of humidity on high temperature oxidation of Inconel 600 alloy: Oxide layers and residual stress study. Applied Surface Science 284, 446 (2013).

7. S. P. Jiang and X. Chen, Chromium deposition and poisoning of cathodes of solid oxide fuel cellsA review. International Journal of Hydrogen Energy 39, 505 (2014).

8. J. Froitzheim, H. Ravash, E. Larsson, L. G. Johansson and J. E. Svensson, Investigation of Chromium Volatilization from FeCr Interconnects by a Denuder Technique. Journal of The Electrochemical Society 157, B1295 (2010).

9. P. Huczkowski, W. Lehnert, H. H. Angermann, et al., Effect of gas flow rate on oxidation behaviour of alloy 625 in wet air in the temperature range $900-1000{ }^{\circ} \mathrm{C}$. Materials and Corrosion 68, 159 (2017).

10. I. Panas, J. E. Svensson, H. Asteman, T. J. R. Johnson and L. G. Johansson, Chromic acid evaporation upon exposure of $\mathrm{Cr}_{2} \mathrm{O}_{3}(\mathrm{~S})$ to $\mathrm{H}_{2} \mathrm{O}(\mathrm{g})$ and $\mathrm{O}_{2}(\mathrm{~g})$ - Mechanism from first principles. Chemical Physics Letters 383, 549 (2004).

11. H. Falk-Windisch, J. E. Svensson and J. Froitzheim, The effect of temperature on chromium vaporization and oxide scale growth on interconnect steels for Solid Oxide Fuel Cells. Journal of Power Sources 287, 25 (2015).

12. M. Stanislowski, E. Wessel, K. Hilpert, T. Markus and L. Singheiser, Chromium vaporization from high-temperature alloys I. Chromia-forming steels and the influence of outer oxide layers. Journal of the Electrochemical Society 154, A295 (2007).

13. J. Froitzheim, S. Canovic, M. Nikumaa, R. Sachitanand, L. G. Johansson and S. E. Svensson, Long term study of $\mathrm{Cr}$ evaporation and high temperature corrosion behaviour of Co coated ferritic steel for solid oxide fuel cell interconnects. Journal of Power Sources 220, 217 (2012).

14. R. Trebbels, T. Markus and L. Singheiser, Investigation of Chromium Vaporization From Interconnector Steels with Spinel Coatings. Journal of Fuel Cell Science and Technology 7, 011013 (2009).

15. C. S. Tedmon, The Effect of Oxide Volatilization on the Oxidation Kinetics of $\mathrm{Cr}$ and Fe-Cr Alloys. Journal of The Electrochemical Society 113, 766 (1966).

16. B. Pujilaksono, T. Jonsson, M. Halvarsson, I. Panas, J. E. Svensson and L. G. Johansson, Paralinear oxidation of chromium in $\mathrm{O}(2)+\mathrm{H}(2) \mathrm{O}$ environment at $600-700{ }^{\circ} \mathrm{C}$. Oxidation of Metals 70, 163 (2008).

17. E. Essuman, G. H. Meier, J. Zurek, M. Hansel, L. Singheiser and W. J. Quadakkers, Enhanced internal oxidation as trigger for breakaway oxidation of $\mathrm{Fe}-\mathrm{Cr}$ alloys in gases containing water vapor. Scripta Materialia 57, 845 (2007).

18. T. Jonsson, B. Pujilaksono, A. Fuchs, J. E. Svensson, L. G. Johansson and M. Halvarsson, The influence of $\mathrm{H}_{2} \mathrm{O}$ on iron oxidation at $600{ }^{\circ} \mathrm{C}$ : A microstructural study, High Temperature Corrosion and Protection of Materials 7, Pts 1 and 2, P. Steinmetz, et al., ed. (2008), p. 1005.

19. G. Hultquist, B. Tveten and E. Hörnlund, Hydrogen in chromium: Influence on the high-temperature oxidation kinetics in $\mathrm{H}_{2} \mathrm{O}$, oxide-growth mechanisms, and scale adherence. Oxidation of Metals $\mathbf{5 4}$, 1 (2000).

20. S. Henry, J. Mougin, Y. Wouters, J. P. Petit and A. Galerie, Characterization of Chromia Scales Grown on Pure Chromium in Different Oxidizing Atmospheres. Materials at High Temperatures 17, 231 (2000).

21. P. J. Meschter, E. J. Opila and N. S. Jacobson, Water Vapor-Mediated Volatilization of High-Temperature Materials. Annual Review of Materials Research 43, 559 (2013). 
22. D. J. Young, Chapter 7-Alloy Oxidation III: Multiphase Scales, in High Temperature Oxidation and Corrosion of Metals (Second Edition), D .J. Young, ed. (Elsevier, 2016), p. 335.

23. J. C. Fisher, Calculation of Diffusion Penetration Curves for Surface and Grain Boundary Diffusion. Journal of Applied Physics 22, 74 (1951).

Publisher's Note Springer Nature remains neutral with regard to jurisdictional claims in published maps and institutional affiliations. 